\title{
MENTÁLNA MAPA V GEOGRAFICKEJ KOGNITÍVNEJ KONŠTRUKCII
}

\author{
Rastislav Čief, Branislav Nižnanský
}

\begin{abstract}
Basic Geographical Education Documents within the School Subject Geography in the Czech and Slovak Republics draw upon the establishment of independent States of the Common Heritage of Czechoslovakia. Twenty-five years after the split, the community of Czech and Slovak geographic and geographic education experts are inspired and often meet at professional events. The article focuses on a description of content standards for geographic education. We focus on a model of geographic thinking that we call a geographic cognitive structure. From our point of view, concepts become geographic in terms of a concept integrated from the mental spatial concepts that individuals acquire through the direct perception of the landscape during its activities in it or indirectly with the work with information objects. We propose corrections of concept and model education models that focus students 'and teachers' attention on concepts, their support for facts and, in particular, geographic contexts, context of interactions and elements placement. We demonstrate the corrections in the example of the analysis of the potential of the thematic areas in terms of spatial differentiation.
\end{abstract}

Keywords: geographical cognitive structure, mental map, mental spatial concepts, concept, conceptual basis, conceptual design, conceptual scheme, landscape perception

\section{Úvod}

Základné dokumenty geografického vzdelávania v rámci školského predmetu Geografia v Českej a Slovenskej republike čerpajú aj po vzniku samostatných štátov zo spoločného dedičstva Česko-Slovenskej republiky. Autori príspevku reflektujú teoretické i praktické zázemie geografického vzdelávania v oboch republikách. Konkrétne boli využité učebnice geografie pre gymnázia, štátny vzdelávací program v SR (obsahový a výkonový štandard) pre predmet geografia, Rámcový vzdelávací program pre predmet geografia aktuálny v ČR a certifikovaná metodika „Koncepce geografického vzdělávání (2017)“ zostavená odborníkmi Karlovej univerzity v Prahe a Masarykovej Univerzity v Brne.

Ciel'om autorov realizovaným hlavne v rámci adaptačného programu (na učitel'stvo geografie) je integrácia teoretických konceptov do praktických vzdelávacích činností. Čiastkové výsledky autori publikovali v dvoch študijných materiáloch (Čief, Nižnanský 2017). Aby bolo možné postavit' (skvalitnit') u študentov základy geografického myslenia zostavili teoretickú schému 
„geografickej kognitívnej konštrukcie (obr. 2)“ ako teoretického zázemia pre návrh formatívnych interakcií (vzdelávacích modulov postavených na štruktúre šiestich typov vzdelávacích ciel'ov, obr. 1). Pre výskum prepojenia teórie a praktických vzdelávacích činnosti bol navrhnutý teoretický koncept geografickej kognitívnej konštrukcie (obr. 2). Termín ,pojem“ používame v zmysle Fregeho (1884) ako triediacu funkciu myslenia nad vecami (predmetmi). Pojem môže plnit' svoju triediacu funkciu vd’aka jeho existencii v pojmových konštrukciách, ktoré vieme opísat' pomocou zoznamov, tabuliek a schém (mind map) a ktoré tvoria podla názoru autorov základ konceptuálnej znalostnej dimenzie v revidovanej Bloomovej taxonómii vzdelávacích ciel'ov (Anderson a Krathwohl 2001).

Obr. 1: Vzdelávacie prostredie s konceptom formatívnej interakcie ako teoretickej bázy vzdelávacích aktivít (Čief, Nižnanský 2017)

Figure 1: Learning environment with the concept of formative interaction as theoreticla basis for educational activities (Čief, Nižnanský 2017)

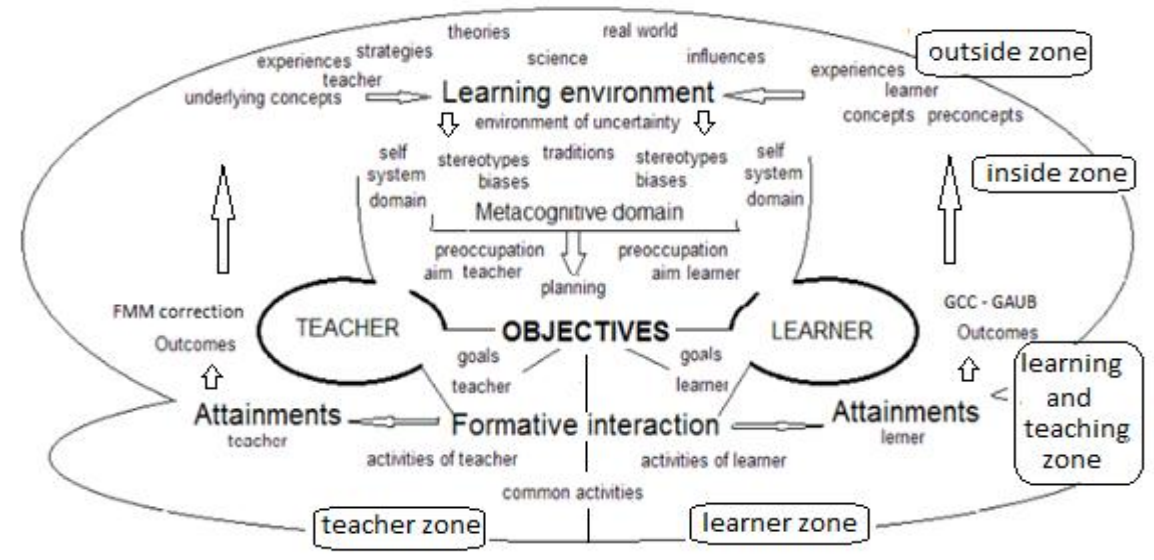

Vnemy prostredia, ku ktorým patrí aj percepcia krajiny možno zaradit' medzi jednoduché kognície (kognitívne schémy). V prácach Ot’ahela (1980, 1996, 2010) sú opisované dve a v práci Sella, Taylora a Zubeho (1983) sú spracované 4 paradigmy: odborná, psychologická, kognitívna a skúsenostná. Nižnanský (1995) využil na výskum percepcie regiónu jeho obyvatel'mi mentálne mapovanie v zmysle Goulda. Podl’a Ot’ahela a Hlavatej (2010) pri analýze vonkajšieho prejavu krajiny a jej vnímania možno vychádzat' z dvoch základných prístupov. Prvý prístup je emocionálny, zmyslový, intuitívny, druhý prístup má kognitívny, poznávací, racionálny základ, vychádzajúci z teoretických konštrukcií, vedeckých metód a nástrojov (Sell, Taylor, Zube, 1983). 
V článku je pozornost' sústredená na teoretický model, ktorého ciel’om je verifikovat' skvalitnenie geografického vzdelávania integrovaním pojmovej zložky v kurikulárnych dokumentoch chápanej ako obsah vzdelávania s mentálnou mapou.

Obr. 2: Geografická kognitívna konštrukcia: Pojmová konštrukcia (Conceptual scheme) je založená na práci s pojmami (ich definíciách, súvislost’ami, hierarchiou atd'.) a na poznaní a percepcii geografických prvkov, procesov a javov priamo v krajine alebo nepriamo cez informačné objekty (tabul'ky, schémy, grafy, obrázky a hlavne mapy) a na budovaní mentálnej mapy (Mental map) s priestorovými predstavami o krajine okolo nás aj o krajine SR, Európy a celého sveta (Čief, Nižnanský 2017)

Figure 2: Geographical cognitive structure: Conceptual scheme is based on working with concepts (their definitions, contexts, hierarchy, etc.) and on the knowledge and perception of geographic elements, processes and phenomena directly in the country or indirectly through information objects (tables, diagrams, graphs, pictures and maps) and Mental maps with spatial ideas about the country around us and about the country of Slovakia, Europe and the whole world (Čief, Nižnanský 2017)

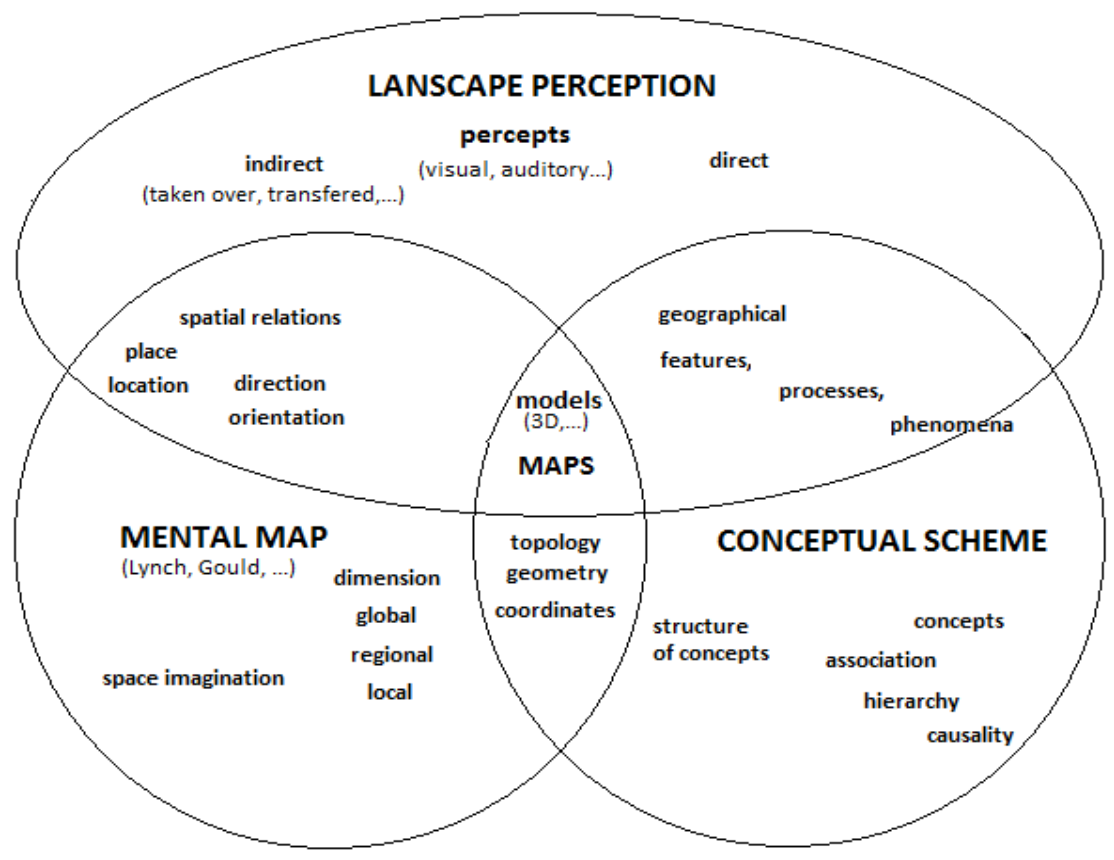




\section{Metodické poznámky}

Filozofickou bázou pre metodický postup, ktorého výsledkom je aj tento článok, je tvrdenie Hvoreckého (2016): „Kým vo fyzike sa všeobecne prijatý názor považuje za výzvu $\mathrm{k}$ jeho vyvráteniu, v pedagogike je bežné chápat' odôvodnený a skúsenost’ami nadobudnutý názor ako akceptovatel'ný a všeobecne prijatel'ný model konania“. Naše tvrdenie (hypotéza) o úzkej súvislosti mentálnej mapy (mentálnych priestorových predstáv) a geografického myslenia (operovania $\mathrm{s}$ geografickými pojmami dokumentujeme v článku odvolaním sa na zdroje počnúc Tolmanovou prácou s roku 1948.

Aby bolo možné realizovat' zámer autorov, ktorým je štandardizácia, prehíbenie a následný rozvoj bázy (jadra) znalostí u študentov nastupujúcich na bakalársky stupeň učitel'ského štúdia geografie, je potrebné zvolit' metodický postup, ktorý bude mat' tieto výstupy:

- návrh konceptuálneho modelu (teoretického rámca, množiny teoretických nástrojov)

- aplikáciu teoretického modelu na vzdelanostný (najmä obsahový) štandard predmetu geografia na ZŠ a SS̆ výberom pojmov pojmovej bázy

- zostavenie operácií (procedúr) s pojmami pojmovej bázy praxou verifikovatel'ných.

Konceptuálny model ako teoretická báza metodického postupu je založený na nasledujúcich konceptoch:

- informačné objekty

- geografická kognitívna konštrukcia, pojmová báza a pojmová konštrukcia, percepcia krajiny, mentálna mapa,

- Brunerove generalizácie, formatívna interakcia a šest' úrovní vzdelávacích ciel'ov.

Základným kritériom tvorby pojmovej bázy je jednoduchost', zrozumitel'nost' a hierarchizácia. Je štruktúrovaná na 10 hlavných tém. V každej je 2 - 5 čiastkových tém. Spolu obsahuje cca 170 hlavných pojmov (v tom je 10 zložených) a cca 160 podpojmov. Termín pojmová báza používame pre pojmovú konštrukciu obsahujúcu istú základnú množinu poznatkov na úrovni pojmov a ich prepojení. Pojmovú bázu geografie sme zostavili (Čief, Nižnanský 2017, Čief, Tomčíková, 2015) analýzou tém a pojmov použitých a verifikovaných vstupným testovaním $\mathrm{v}$ rámci adaptačného programu na bakalársky študijný program geografie na KU v Ružomberku a TU v Liberci.

S pojmovou bázou úzko súvisí koncept „Brunerove generalizácie“, ktorý prirad'ujeme našej analýze testových položiek (obr. 4) a následne využívame pri zostavení cvičení a testových položiek Inšpiráciou boli aj práce Likavského (Likavský, 2016, Likavský a Jančiček, 2016 a Likavský s Černou, 2014). Pre 
operácie (procedúry) s pojmami sme aplikovali nasledujúce úlohy. Vypísat' si a naučit' sa pojmy desiatich tém pracovných listov, dávat' ich do súvislostí v nasledovných situáciách (Čief, Nižnanský 2017, s. 37-38):

- zostavovat' text obsahujúci pojmy danej témy

- k piatim pojmom témy pridat' d'alších 5 súvisiacich a odôvodnit' súvislost'

- $\mathrm{k}$ triede prvkov ( $\mathrm{k}$ pojmu) vymenovat' príklady jej podtried alebo konkrétnych prvkov

- ku geografickému prvku, procesu alebo javu opísat' zvyšné dva objekty (napríklad $\mathrm{v}$ akom procese môže vzniknút' prvok x, ako sa nám javí)

- z desiatich pojmov témy opísat' vlastnými slovami až definovat' 3 - 6

- dokázat' pre pojmy danej témy nájst' pomocou atlasu alebo internetu konkrétne súvislosti v regiónoch Európy alebo sveta

- charakterizovat' vybraný región pomocou vybraných pojmov témy

- zostavit' pojmovú schému z pojmov témy, opísat' jej hlavné a vedlajšsie pojmy a ich súvislosti.

V článku nás zaujímajú operácie s pojmami integrujúce procedúry $\mathrm{s}$ mentálnou mapou. Uvedený návrh operácií (procedúr) s pojmami pojmovej bázy zostavíme tak, aby jeho konkrétne položky obsahovali prácu s mentálnou mapou a jej aplikáciu $\mathrm{v}$ cvičeniach a testových položkách adaptačného programu študentov nastupujúcich na bakalársky stupeň štúdia učitel'stva geografie.

\section{Pojmová štruktúra základ obsahového štandardu}

Ciel'om aktivít formatívnej interakcie „Diagnostický a vstupný test“ realizovaných dve desat'ročia so začínajúcimi študentmi bakalárskeho stupňa učitel'stva geografie bolo spočiatku zistit' úroveň výstupu geografického vzdelávania, dnes výstupu zo Štátneho vzdelávacieho programu v SR (obsahový a výkonový štandard) pre predmet geografia a Rámcového vzdelávacieho programu pre predmet geografia aktuálneho v ČR.

Pri analýze výsledkov testov sme zistili potrebu prepracovanejšieho teoretického základu ich zostavovania. Ovplyvnili nás odborné články o Bloomovej taxonómii edukačných ciel'ov. Následkom zahltenia teóriou sa hlavným ciel'om stalo zjednodušenie teoretickej bázy, aby sme sa dostali k formulovaniu zadaní aktivít a ich korekcii na základe reflexie ich výstupov (pozri obr. 1).

Termíny „pojem“ a „koncept“ tu chápeme a používame ako synonymá. Pojem nemôže existovat' sám o sebe je súčastou kognitívnej štruktúry (obr. 2 a 4), ktorú z didaktického hladiska zjednodušene reprezentuje množina vybraných pojmov a ich súvislostí (v prvom rade pojmová báza). Pôvodná Bloomova taxonómia bola na prelome tisícročí $\mathrm{v}$ kognitívnej (poznatkovej) oblasti rozpracovaná ako dvojrozmerná štruktúra (obr. 3). Tvorí ju dimenzia znalostí 
(znalostnú dimenziu), ktorá má štyri úrovne: fakty, pojmy/konceptuálne poznatky, procedurálne poznatky a metakognitívne poznatky (Anderson a Kratwohl, 2001). Primárne sme úroveň faktov, pojmov ale čiastočne aj procedúr a metakognícií využili na analýzu testových položiek. Pri analýze testových položiek použivaných do roku 2016 sme sa zamerali na faktické a konceptuálne poznatky (fakty a pojmy). Vybrali sme otázky, pri ktorých mal študent uviest' nejaký fakt (napríklad názov rieky, plochu svetového oceánu, plyn prevažujúci v zložení troposféry), alebo mal objasnit’ nejaký pojem.

Obr. 3: Revidovaná Bloomova taxonómia vzdelávacích cielov (Anderson a Krathwohl, 2001, zohl'adnený je rozvoj kognitívnej vedy, preklad a doplnenie aktívnych slovies podla viacerých zdrojov realizovali autori)

Figure 3: Revised Bloom's Taxonomy of Educational Goals (Anderson and Krathwohl, 2001, the development of cognitive science, the translation and the addition of active verbs by multiple sources were taken into account by the authors)

\begin{tabular}{|c|c|c|c|c|c|c|}
\hline & \multicolumn{6}{|c|}{ DIMENZIA KOGNITIIVNEHO PROCESU } \\
\hline $\begin{array}{l}\text { ZNALOSTNÁ } \\
\text { DIMENZIA }\end{array}$ & 1. Zapamätat' si & 2. Porozumiet & 3. Aplikovat' & 4. Analyzovat' & 5. Hodnotit & 6.Tvorit' \\
\hline $\begin{array}{l}\text { A. } \\
\text { faktické } \\
\text { poznatky }\end{array}$ & $\begin{array}{l}\text { vymenovat', } \\
\text { uviest' }\end{array}$ & $\begin{array}{l}\text { stručne } \\
\text { vyjadrit', zhrnút }\end{array}$ & $\begin{array}{l}\text { roztriedit', } \\
\text { klasifikovat' }\end{array}$ & usporiadat' & $\begin{array}{l}\text { zatriedit' } \\
\text { vybrat' }\end{array}$ & kombinovat' \\
\hline $\begin{array}{l}\text { B. } \\
\text { konceptuálne } \\
\text { poznatky }\end{array}$ & opisat' & $\begin{array}{l}\text { interpretovat' } \\
\text { rozoznat }\end{array}$ & experimentovat' & $\begin{array}{l}\text { vysvetlit' } \\
\text { porovnat' }\end{array}$ & $\begin{array}{l}\text { odhadnút' } \\
\text { určit' }\end{array}$ & $\begin{array}{l}\text { plánovat' } \\
\text { načrtnút' }\end{array}$ \\
\hline $\begin{array}{l}\text { C. } \\
\text { procedurálne } \\
\text { poznatky }\end{array}$ & usporiadat' & Predpokladat' & $\begin{array}{l}\text { vypočitat' } \\
\text { riešit' }\end{array}$ & $\begin{array}{l}\text { rozlišovat' } \\
\text { znázornit' }\end{array}$ & $\begin{array}{l}\text { vyvodit', } \\
\text { usúdit' }\end{array}$ & $\begin{array}{l}\text { vytvorit' } \\
\text { poskladat' } \\
\text { navrhnút' }\end{array}$ \\
\hline $\begin{array}{l}\text { D. } \\
\text { metakognitivne } \\
\text { poznatky }\end{array}$ & použit' & Spracovat' & skonštruovat' & vytvorit' & $\begin{array}{l}\text { vykonat' } \\
\text { vyjadrit' }\end{array}$ & $\begin{array}{l}\text { aktualizovat' } \\
\text { zdokonalit' }\end{array}$ \\
\hline
\end{tabular}

Ukázalo sa, že všetky otázky na fakty sú založené na pojmovej konštrukcii. $\mathrm{Na}$ obr. 4 vidíme grafické znázornenie pojmov a faktov v štyroch typoch otázok. Otázky zamerané na fakty (A1 a A2) majú v našom prístupe zložitejšiu štruktúru ako otázky zamerané na pojmy (B1 a B2). Okrem triedy (pojmu) alebo prvkov tejto triedy (alebo jej podtried požadovaných v otázkach zameraných na pojmy (B1 a B2) sa po žiakoch v otázkach A požadujú aj fakty: konkrétne príklady (vlastné mená), atribúty prvkov (tried) a často ich hodnoty bud' kvalitatívne alebo kvantitatívne. 
Obr. 4: Štruktúra testových otázok používaných v adaptačnom programe. Využitý je princíp Vennovho diagramu pre pojmy ako triedy a prvky (podtriedy) a pojmová schéma typu strom pre atribúty a ich hodnoty (vybrané $\mathrm{z}$ analýz autorov)

Figure 4: Structure of test questions used in the adaptation program. The principle of the Vennov diagram for terms such as classes and elements (subclasses) and conceptual tree pattern for attributes and their values (selected from author analyzes)
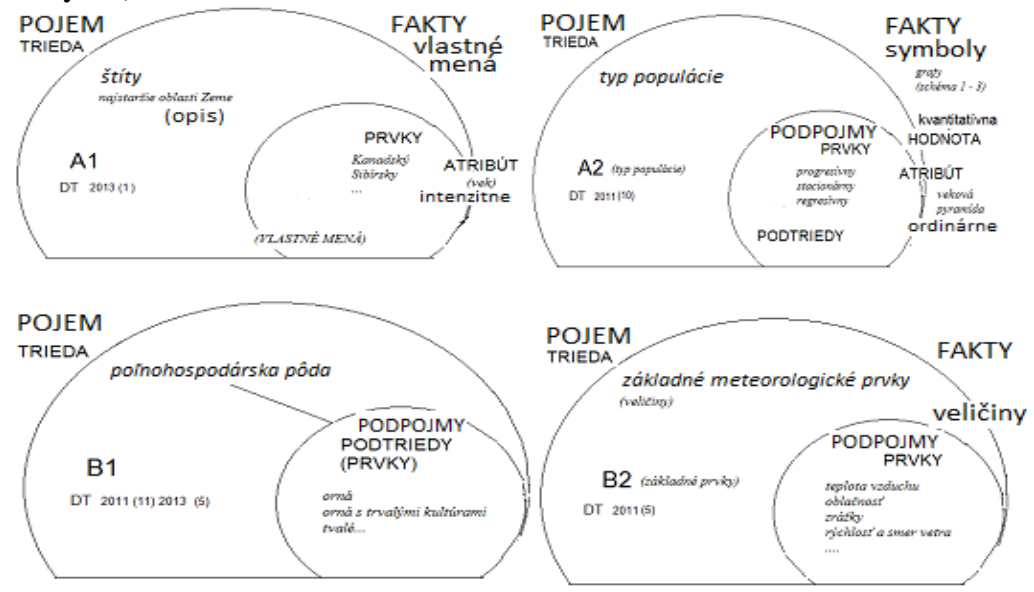

Obr. 5: SOLO taxonómia s príkladmi slovies indikujúcich stupeň osvojenia (Biggs, Collis, 1982)

Figure 5: SOLO taxonomy with examples of words indicating the degree of adoption (Biggs, Collis, 1982)

\begin{tabular}{|c|c|c|c|c|c|}
\hline \multirow{14}{*}{ 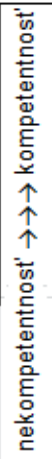 } & & & & & tvorit \\
\hline & & & & analyzovat & formulovat \\
\hline & & & & aplikovat & zovšeobecrovovat' \\
\hline & & & & argumentovat & predpokladat \\
\hline & & & & porovnávat/kontrast & reflektovat \\
\hline & & & kombinovat & kritizovat & teoretizovat \\
\hline & & & opisovat & vysvetlovat pričiny & \\
\hline & & identifikovat & vymenúvat & zistovat súvislost & \\
\hline & & pomenúvat & robit' sériu krokov & dokladat (faktmi) & \\
\hline & & opakovat' procedúru & zostavovat zoznam & & \\
\hline & & (krok) & & & \\
\hline & zlyhávat & & & & \\
\hline & strácat nit & & & & \\
\hline & nebyt komepetentný & & & & \\
\hline ?c. & $\begin{array}{c}\text { Preštrukturálna } \\
\text { (pozri Piagetove } \\
\text { prekoncepty) }\end{array}$ & $\begin{array}{c}\text { Uništrukturálna } \\
\text { jeden relevantný } \\
\text { aspekt }\end{array}$ & $\begin{array}{l}\text { Multištrukturálna } \\
\text { viac nezávislých } \\
\text { relevantných } \\
\text { hl'adisk (aspektov) }\end{array}$ & $\begin{array}{l}\text { Relačná } \\
\text { integrovat' do } \\
\text { štruktúry }\end{array}$ & $\begin{array}{c}\text { Rozširenie } \\
\text { abstraktu } \\
\text { zovšeobecnit do } \\
\text { novej oblasti } \\
\text { (analógia, transfer) }\end{array}$ \\
\hline
\end{tabular}


Miera abstrakcie je pri diagramoch na obr. 4 odlíšená číslom. Otázky A1 a B1 obsahujú jednoduché geografické pojmy navzájom súvisiace. Otázky A2 a B2 obsahujú aj pojmy, ktoré rozširujú geografickú pojmovú konštrukciu o všeobecné pojmy mimo geografie (napríklad pojmy ako: celok, základný prvok, proces, druh, typ...). Štruktúrna analýza v tomto príklade naznačuje zložitost' problému zapojenia najmä slabších študentov do štúdia t. j. spojenie geografických a negeografických pojmov (často jednotlivo nezrozumitel'ných) do súvislostí Skúsenosti z analýzy nás smerujú $\mathrm{k}$ potvrdeniu priority úrovne „konceptuálne poznatky“ aj $\mathrm{v}$ úrovni „faktické poznatky“" (nie sú možné fakty bez pojmovej štruktúry), ale aj vo vyšších úrovniach teoretickej schémy na obr. 4 (procedúry sa realizujú $\mathrm{s}$ pojmami a faktami a metakognitívne znalosti máme v prvom rade o pojmových štruktúrach).

Uvedená analýza je analogická postupu, ktorý na základe Brunerových prác (1966, 1996) realizovali autori Koncepce geografického vzdělávání (2017, str. 19). Autori následne smerujú operovanie s pojmami do zostavenia bázovej množiny tvrdení. My sme postupovali analogicky ale primárne sme zostavili množinu pojmov, ktorú sme nazvali pojmová báza. Nad pojmovou bázou sme konštruovali úlohy na prácu s pojmami od precvičovania pojmových štruktúr až po konštrukciu tematických tvrdení a ich reflexiu. Nástrojom pre pochopenie problému merania výsledkov práce s pojmami sa javí SOLO taxonómia (obr. 5). Zjednodušený je problém pojmovej štruktúry $\mathrm{v}$ kontexte zložitej analýzy pojmov $\mathrm{v}$ geografickej kognitívnej konštrukcii (obr. 2) ale aj v kontexte štyroch úrovní znalostí (faktov, pojmov, procedúr a metakognícií uvedených na obr. 3). Najmä porovnanie aktívnych slovies oboch taxonómií (obr. 3 a 5) nás naviguje $\mathrm{k}$ lepšiemu formulovaniu úloh pre budovanie pojmovej bázy geografie.

Výhodou SOLO taxonómie je možnost' zjednodušenia zložitej kognitívnej konštrukcie zameraním sa na pojmy (prekoncepty) a ich asimiláciu až akomodáciu v zmysle Piageta (1993 a 1999). Je podl'a nás základom pre najdôležitejšiu čast' formatívnych interakcií, ktorou je hodnotenie výsledkov, identifikácia chýb a spoločného hl'adania spôsobov ich predchádzania a odstraňovania.

Opísané postupy obsahujú nástroje behavioristického kognitívneho aj konštruktivistického prístupu $\mathrm{k}$ vyučovaniu a učeniu. Práca s reálnou krajinou a informačnými objektmi o krajine hlavne mapami je d’alší s problémov, ktorý riešime na vstupe do bakalárskeho stupňa. Skúsenosti z teoretickej i praktickej činnosti sme zhrnuli v schéme geografickej kognitívnej konštrukcie (obr. 2). Samotná práca s informačnými objektmi o krajine najmä mapovými zobrazeniami (z atlasov, internetu a podobne) môže byt' podnetom rozvoja konektivistického prístupu ku vzdelávaniu. Jej ciel'om je budovanie a rozvoj mentálnej mapy integrovanej do geografickej kognitívnej konštrukcie. 


\section{Mentálna mapa integrálna súčast' geografickej kognitívnej konštrukcie}

Slovné spojenie mentálna mapa sa $\mathrm{v}$ literatúre používa $\mathrm{v}$ troch kontextoch. Prvý $\mathrm{v}$ spojitosti $\mathrm{s}$ behaviorálnou geografiou založený na prácach Lyncha (1960), Goulda a Whitea (1986) a i. V n̆om je mentálna mapa reprezentáciou kognitívnej schémy získanej percepciou atribútov konkrétnych miest spojených so správaním, preferenciami a pocitmi jednotlivca (Kramáreková et al. 2016 a,b). Druhé použitie termínu súvisí s psychológiou a kognitívnou vedou. Pojem „mentálna mapa“ sa používa na vyjadrenie pojmu ,pojmová schéma“. V literatúre nachádzame d’alšie diskutabilné alternatívy „mind map, mental map, conceptual map, Cmap“ napr. Karolčík a Murtinová (2013). Termín mapa sa z pohl'adu geografie javí byt' neadekvátnym nahradením termínu „schéma“, ktorý v kontexte osvojovania pojmov použil napr. Piaget $(1993,1999)$. „Mentálnu mapu v mysli“ podl'a Bella (2009, in Vávra 2010, podl'a Tolman, 1948) „kognitívnu mapu“ sme označili termínom „mentálne priestorové predstavy“ (Nižnanský, 1993). Termín „mentálna mapa“ používame aj v užšom chápaní ako grafickú reprezentáciu mentálnych priestorových predstáv (Lynch, 1960, Gould a White, 1986).

Autori Koncepce geografického vzdělávání (2017) sa zaoberajú využitím mentálnej mapy pri vzdelávaní ,... myšlení jedince se realizuje souborem vzájemně propojených procesů, které operují slovy (např. názvy, daty, odbornými pojmy, symboly), větami (např. výroky, principy), ale i názornými představami např́. mentální mapami“ (str. 15). V rámcovom vzdelávacom programe $\check{C} R$ (2017) má žiak byt' schopný využit' „vlastnú mentálnu mapu“ na orientáciu na konkrétnom území. Termín vlastná mentálna mapa tu zodpovedá viac nášmu chápaniu termínu „mentálne priestorové predstavy“. V predchádzajúcich prácach sme sa zamerali na geografický aspekt termínu.

Mentálna mapa $\mathrm{v}$ geografii je často chápaná ako kognitívna štruktúra (Tolman, 1948) inokedy ako jej grafická reprezentácia. Obsahuje obrazy topografických (pozri aj Rakytová a Tomčíková, 2018) a geografických prvkov a javov, ktoré sú v mysli spojené $\mathrm{s}$ priestorovými a nepriestorovými atribútmi (Nižnanský, 1993 a 1994) získanými percepciou informačných objektov a zo životných zážitkov. Využitím mentálnej mapy (mentálnych priestorových predstáv) rozširujeme pojmovú schému geografických objektov o priestorové atribúty ako sú poloha (súradnice, vzdialenost'), pôdorys (polygón, línia), topologické relácie (susedí, leží na, je väčší) a relácie smeru a orientácie (severne, rovnobežkový smer). Potrebu odlíšit' kogníciu od jej reprezentácie nájdeme aj v Koncepci ... (2017, str. 15 pozri vyššie, resp. str. 13): „Imaginativní myšlení pracuje s názornými obrazy, představami. Vyvoláme ho např́iklad otázkou: Jak asi vypadá př́roda $\mathrm{v}$ létě na Islandu? Má úzkou souvislost s tvorbou a používáním mentálních map, tj. s mapami území v mysli jedincư“.

Tvrdenie o úzkej súvislosti mentálnej mapy (mentálnych priestorových predstáv) a geografického myslenia (geografických pojmov) tvorí aj základ 
schémy geografickej kognitívnej konštrukcie (obr. 1). Schéma vznikla ako teoretický rámec pre zodpovedanie klúčových otázok: Ako funguje prepojenie a vzájomná podpora pojmovej konštrukcie a mentálnej mapy? Ako možno merat' výstup geografického myslenia založený na integrácii pojmovej štruktúry a mentálnej mapy? Je možné dosiahnutie ciel’ov geografického vzdelávania (napríklad ciel': zodpovedný manažment krajiny občanmi) merat' v praxi inak ako všeobecne prijatými tvrdeniami?

\section{Prepojenie mentálnej mapy a pojmovej štruktúry}

Pre reflexiu výstupov realizácie úloh a dosiahnutia ciel'a geografického vzdelávania, ktorým je na báze znalostí zodpovedne realizovaný manažment krajiny obce, regiónu až celej planéty potrebujeme analýzu exitujúceho stavu. Analyzovali sme viacero dokumentov a hl'adali využitie mapy $\mathrm{v}$ tematickom okruhu „Litosféra“. V nasledujúcich ukážkach sú podčiarknuté pojmy s reláciou k mentálnej mape. Štátny vzdelávací program SR (predmet Geografia: výkonový štandard) - ukážka potenciálu využit' mentálne mapy v prvých troch tematických celkoch z desiatich (ŠPU 2017 str. 4, 5 - d'alej ŠVP):

1. Zdroje poznávania $v$ geografii - určit' polohu l'ubovol'ného miesta na mape pomocou geografických súradníc (mapa: Európa všeobecnozemepisná mapa) - využívat' poznatky v rôznych grafických podobách (mapa: Slovensko - Hustota zal'udnenia)

V ŠVP možno identifikovat' požiadavky na zručnosti, ktoré by mohli prepojit' všetky tri zložky geografickej kognitívnej konštrukcie: navrhnút' trasu geografickej exkurzie (vychádzky) a naplánovat' jej program, odhadnút' náročnost' prístupu k zaujímavým bodom na turistickej mape (vrcholy, kultúrno-historické a prírodné pamiatky, str. 10), zhodnotit' polohu regiónu a identifikovat' ho na mape (str. 12).

Rámcový vzdelávací program ČR (predmet Geografia: očakávané výstupy žiaka) - ukážka potenciálu využit' mentálne mapy v prvom tematickom celku z piatich:

1. Prírodné prostredie - objasní mechanizmy globálnej cirkulácie atmosféry a jej dôsledky na vytvorenie klimatických pásiem (mapa: Svet-Atmosféra) - rozlíši hlavné biómy sveta (mapa: Svet - Biosféra a prírodné krajiny)

Úlohy na prácu s mapou až po využitie mentálnych schém a mentálnych máp nájdeme na str. 35 a 36.

Fyzická geografia (rozsah: $1 / 3$ štátnice $\mathrm{Bc}$ ) - sylaby $\mathrm{k}$ téme georeliéf/litosféra (44\% fyzickej geografie) - ukážka prvého sylabu $\mathrm{z}$ dvanástich venovaných problematike litosféry a georeliéfu:

1. Stavba a zloženie Zeme, litosféra, základné typy zemskej kôry vymedzenie a základná charakteristika (mapa: Svet - Fyzická mapa s reliéfom morského dna). 
Autori „Koncepce geografického vzdělávání (2017) využili na pojmovú konštrukciu (obsah geografického vzdelávania) Brunerove koncepty: Príklad z témy sídla: „TVRZENÍ: Proměna přírodních a společenských podmínek v různých částech světa vede ke vzniku či proměně směru a intenzity migračního pohybu obyvatel. POJMY: Př́rodní podmínky, společenské podmínky, migrace. FAKTA: Např. Hodnota HDP ve zdrojových zemích migrace a její vývoj jako ukazatel společenských podmínek.“ (Koncepce...,str. 19)

\section{Prepojenie mentálnej mapy a pojmovej schémy}

Zostavenie základných cvičení a testov k štandardizácii pojmovej bázy a budovaniu resp. upevneniu základov mentálnej mapy ukazujeme na publikovaných (Čief, Nižnanský 2017, str. 39-57) pracovných listoch, ktorým predchádzalo opísané zostavenie pojmovej bázy. Pojmy sú vybrané z dostupných kurikurálnych dokumentov a učebníc autormi vyššie opísaným postupom.

\section{Záver}

Z doterajších skúseností možno konštatovat', že hypotéza o úzkej súvislosti mentálnej mapy (mentálnych priestorových predstáv) a geografického myslenia (operovania s geografickými pojmami) je dokumentovatel'ná aj obsahom kurikula aj ukážkou konkrétnych úloh a cvičení. Ďalej možno konštatovat', že na základe našich skúseností úlohy s mapou majú silný motivačný náboj. Otvorenou je otázka zmeny myslenia vyučujúcich a tým aj študentov.

Tam kde je používanie atlasov povolené, je problémom zmena myslenia. Väčšia čast' formulácií zadaní tematických okruhov pre štátnu skúšku je formulovaná ako požiadavka na pojmy a fakty na úrovni zapamätat'. $V$ texte práce sme na základe našich skúseností a uvedených zdrojov vyslovili dve nové všeobecne akceptované tvrdenia resp. hypotézy (Hvorecký, 2016), ktoré súvisia s primárne formulovaným tvrdením o úzkej súvislosti mentálnej mapy (mentálnych priestorových predstáv) a geografického myslenia (operovania s geografickými pojmami).

Prvé je zamerané na hypotézu o chybe v didaktickej praxi „Klasické požadovanie všetkých vlastných mien sa v uvedenom kontexte javí ako didaktická chyba“ druhé o motivačnom náboji práce študentov s mapou (pozri vyššie). Aj napriek všeobecne prijatým tvrdeniam, ako aj predikcii teoretických konceptov smerom ku konkrétnym aplikáciám prezentovaným vyššie zostávajú viaceré otázky otvorené. Aj tie položené v tomto článku:

Ako funguje prepojenie a vzájomná podpora pojmovej konštrukcie a mentálnej mapy? Ako možno merat’ výstup geografického myslenia založený na integrácii pojmovej štruktúry a mentálnej mapy? Je možné merat' dosiahnutie ciel'ov geografického vzdelávania $\mathrm{v}$ praxi inak ako všeobecne prijatými tvrdeniami? (napríklad zodpovedný manažment krajiny občanmi). 


\section{Literatúra}

ANDERSON, L. W. - KRATHWOHL, D. R. 2001. A Taxonomy for Learning, Teaching and Assessing. Abridged: Addison Wesley Longman, Inc. 302 p. ISBN 0-8013-1903-X.

BELL, S. 2009. Mental Maps. In Kitchin, R., Thrift, N. (eds.) Geography, International Encyclopedia of Human Geography, vol. 7, Elsevier, Oxford, pp. 70-75

BIGGS, J. B. - COLLIS, K. F. 1982. Evaluating the quality of learning: The SOLO taxonomy (Structure of the Observed Learning Outcome). New York: Academic Press.

BLOOM, B. - ENGLEHART, M. - FURST, E. - HILL, W. - KRATHWOHL, D. 1956. Taxonomy of educational objectives: The classification of educational goals. Handbook I: Cognitive domain. New York, Toronto: Longmans, Green.

BRUNER, J. 1966. Toward a theory of instruction. Cambridge: Harvard University Press.

BRUNER, J. 1996. The culture of education. Cambridge, MA : Harvard Univ. Press.

ČERNÁ, M. - LIKAVSKÝ, P. 2014. Klúčové kompetencie v geografickom vzdelávaní a možnosti ich rozvíjania. In Geografia. ISSN 1335-9258, 2014, roč. 22 , č. 2 , s. 55-59.

ČIEF, R. - NIŽNANSKÝ, B. 2017. Geografia - začíname aktívne. Ružomberok: Verbum, 2017. ISBN 978-80-561-0503-0.

ČIEF, R. - TOMČÍKOVÁ, I. 2015. The conceptual base of environmental education of future geography teachers. In 15th International Multidisciplinary Scientific Geoconference SGEM 2015, Ecology, Economics, Education and Legislation Conference Proceedings, Volume III. Enviromental Economics, Education and Accreditation in Geosciences 18.-24.6.2015, Albena. ISBN 978619-7105-41-4, pp. 1003-1010.

FREGE, G. 1884. Die Grundlagen der Arithmetik - Eine logisch mathematische Untersuchung über den Brgiff der Zahl; Verlag von Wilhelm Koebner: Breslau. GOULD, P. - WHITE, R. 1986. Mental Maps. New York: Routledge, 1986. 184 p. ISBN 978-0415084826.

HAWKING, S. W. 2003. Stručná historie času. Mladá Fronta: Praha, 1988.

HVORECKÝ, J. 2016. Pedagogika - objav 21. storočia?. Dostupné na internete: https://blog.etrend.sk/jozef-hvorecky/pedagogika--objav-21-strocia.html

JANČIČEK, M. - LIKAVSKÝ, P. 2016. Schopnosti žiakov ZŠ a SŠ riešit' geografické úlohy spojené $\mathrm{s}$ informáciami v grafickej podobe. In Inovácie a trendy v prírodovednom vzdelávaní. Bratislava: Univerzita Komenského, 2016. ISBN 978-80-223-4175-2. s. 99-105.

KAROLČÍK, Š. - MURTINOVÁ, L. 2013. Pojmové mapy a nástroje na ich tvorbu. In Geografické rozhledy. ISSN 1210-3004, 2013, roč. 23, č. 4, s. 12-14. 
KRAMÁREKOVÁ, H. - NEMČÍKOVÁ, M. - RAMPAŠEKOVÁ Z. - SVORAD, A. - DUBCOVÁ A. - VOJTEK M., 2016. Cartographic Competence of a Geography Teacher - Current State and Perspective. In 6th International Conference on Cartography \& GIS : June 2016, Albena, Bulgaria. ISSN 13140604. pp. 200-209.

KRAMÁREKOVÁ, H. - NEMČÍKOVÁ, M. - DUBCOVÁ, A. - VOJTEK, M. GAJDOŠÍKOVÁ, B. - KONEČNÝ, M. 2016. Comparison of Cartographic Language of Pupils in the 4th Grade of Primary School (Case study) of the Slovak Republic and Czech Republic. In 6th International Conference on Cartography \& GIS : 13-17 June 2016, Albena, Bulgaria. ISSN 1314-0604. pp. 176-187.

LIKAVSKÝ, P. 2016. Schopnosti študentov učitel'stva geografie riešit' úlohy spojené $\mathrm{s}$ informáciami $\mathrm{v}$ grafickej podobe. In Inovácie a trendy $v$ prírodovednom vzdelávaní. Bratislava: Univerzita Komenského, 2016. ISBN 978-80-223-4175-2, pp. 121-126.

LYNCH, K. 1982. Obraz goroda. Moskva: Strojizdat, 1982. $327 \mathrm{~s}$.

MARADA, M. - ŘEZNÍČKOVÁ, D. - HANUS, M. - MATĚJČEK, T. HOFMANN, E. - SVATOŇOVÁ, H. - KNECHT, P. 2017. Koncepce geografického vzdělávání. Certifikovaná metodika. Praha, 2017.

NIŽNANSKÝ, B. 1993. Mentálne schopnosti vo vzt'ahu ku krajine a mape. In Kartografické listy. SKS a GÚ SAV, Bratislava, č. 1, s. 37-45.

NIŽNANSKÝ, B. 1994. Mentálna mapa a profesionálne mapové diela. In Kartografické listy. SKS A GÚ SAV, Bratislava, č. 2, s. 61-70.

NIŽNANSKÝ, B. 1995. Interpretácia percepcie regiónu na príklade východného Slovenska. In AF Pedagogicae Universitatis Šafarikanae, XXVI, biológia geografia, Prešov, s. 253-272.

OŤAHEL, J. - HLAVATÁ, Z. 2010. Krajina jej vnímanie, prístupy k analýze. In AFSHeN UNIVERSITATIS PREŠOVIENSIS, Prírodné vedy, XL., Folia Geographica 16, ISSN 1336-6157, s. 23-35.

PIAGET, J. 1999. Psychologie inteligence. Praha: Portál, 1999. 164 s. ISBN 807178-309-9.

PIAGET, J. - INHELDEROVÁ, B. 1993. Psychológia diet'at'a. Bratislava: SOFA, 1993. 141 s. ISBN 80-85752-33-6.

RAKYTOVÁ, I. - TOMČÍKOVÁ I. 2018. Geography of local landscape in the educational processin primary scholl in Slovakia. In European Journal of Geography. ISSN 1792-1341, 2018, vol. 9, no. 1, pp. 49-61.

SELL, G. L. - TAYLOR, J. G. - ZUBE, E. H. 1983. Landscape perception: research, application and theory. In Landscape Planning. vol. 9, pp. 1-33.

SLAVÍK, J. - STARÁ, J. - ULIČNÁ, K. - NAJVAR, P. 2017. Didaktické kazuistiky v oborech školního vzdělávání. Brno: Masarykova univerzita. s. 1146, 36 s. ISBN 978-80-210-8758-3.

ŠPU, 2017. Štátny vzdelávací program pre gymnáziá: Človek a spoločnost’ 
Geografia. Dostupné na internete: http:/www.statpedu.sk/sk/svp/inovovanystatny-vzdelavaci-program/inovovany-svp-gymnazia-so-stvorrocnympatrocnym-vzdelavacim-programom/clovek-spolocnost/

TOLMAN, E. C. 1948. Cognitive maps in rats and men. In Psychological Review. vol. 55 , no. 4 , pp. 189-208.

VÁVRA, J. 2009. Místo (place) v regionální geografii a v geografickém vzdělávání. In Acta Geographica Universitatis Comenianae. roč. 52, s. 119127.

VÁVRA, J. 2010. Jedinec a místo, jedinec v místě, jedinec prostřednictvím místa. In Geografie. roč. 115, č. 4, s. 461-478.

VÝSKUMNÝ ÚSTAV PEDAGOGICKÝ. 2007. Rámcový vzdělávací program pro gymnázia. VUP Praha, ISBN 978-80-87000-11-3. Dostupné na internete: http://www.msmt.cz/vzdelavani/skolstvi-v-cr/skolskareforma/ramcovevzdelavaci-programy

\section{MENTAL MAP IN A GEOGRAPHIC COGNITIVE STRUCTURE}

\section{Summary}

Basic Geographical Education Documents within the School Subject Geography in the Czech and Slovak Republics draw upon the establishment of independent States of the Common Heritage of Czechoslovakia. Twenty-five years after the split, the community of Czech and Slovak geographic and geographic education experts are inspired and often meet at professional events at an abovestandard frequency.

The long-standing issue of education is its content. The article focuses on a description of content standards for geographic education. We focus on a model of geographic thinking that we call a geographic cognitive structure. The exception of the model we have proposed to adapt bachelor students to geography studies is the integration for geography of specific cognitions such as landscape perception and mental map. From our point of view, concepts become geographic in terms of a concept integrated from the mental spatial concepts that individuals acquire through the direct perception of the landscape during its activities in it or indirectly with the work with information objects. In geographic education, it is generally recognized that the most important information objects for building and deepening a mental map are map views and multiple landscape images (schemes, blocks, photographs, drawings, 3D models, etc.). The contribution is based on the supportive meaning of concepts within the taxonomy of learning goals (Bloom, 1956, Biggs and Collis, 1982, Krathwohl and Anderson, 2001) that thinking is an operation with concepts. We propose a theoretical model aimed at verifying the improvement of geographic education by integrating the conceptual component in curricular documents, understood as a content of learning with a mental map. At 
the same time, we propose corrections of concept and model education models that focus students 'and teachers' attention on concepts, their support for facts and, in particular, geographic contexts, context of interactions and elements placement. We demonstrate the corrections in the example of the analysis of the potential of the thematic areas in terms of spatial differentiation.

The previous experience has shown that the hypothesis of a close relationship between the mental map (mental space images) and geographical thinking (the use of geographic concepts) is also documented by the content of the curriculum and the demonstration of specific tasks and exercises. In addition, based on our experience with the map, they have a strong incentive charge. The question of changing the teachers' way of thinking as well as students' is still open. Most of the State Exam thematic areas' formulations are formulated as a requirement for remembering the terms and the facts. The impact of this behavioral model is the reproduction of knowledge at the level of preconceptions and isolated facts. Despite the pressure, four students out of five do not use maps to demonstrate the presented knowledge during the examination. However, it should be noted that where the use of atlases is recommended, we can see the improvement in both, the teachers and the students. Under the Improvement we understand a more frequent use and greater variability of the maps and the information obtained with them.

\section{PaedDr. Rastislav Čief, PhD.}

Katolícka univerzita

Hrabovská cesta 1, Ružomberok

E-mail: rastislav.cief@ku.sk

Doc. RNDr. Branislav Nižnanský, CSc.

Technická univerzita

Studentská 1402/2, Liberec

E-mail: branislav.niznansky@tul.cz 